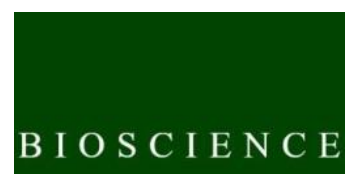

J O U R N A

\title{
POTENTIAL DEGRADATION AND COLONIZATION TIME OF RUMINAL MICROORGANISMS ON THE PARTICLES OF DIFFERENT OILSEEDS-CRUSHED, AND ITS CHEMICAL COMPOSITION
}

Rafael Henrique de Tonissi e Buschinelli de GOES ${ }^{1}$ iD, Kennyson Alves de SOUZA ${ }^{2}$ iD, Milene Puntel OSMARI ${ }^{3}$ (D), Thiago José de Lira CARDOSO ${ }^{4}$ (D) Raquel Tenório de OLIVEIRA ${ }^{4}$ (iD), Nayara Gonçalves da SILVA ${ }^{4}$ iD, Jefferson Rodrigues GANDRA ${ }^{5}$ iD, Luiz Carlos Ferreira de SOUZA ${ }^{1}$ iD

${ }^{1}$ College of Agricultural Sciences, Federal University of Grande Dourados, Dourados, Mato Grosso do Sul, Brazil.

2 Department of Animal Science, Environmental and Biological, Federal University of Recôncavo da Bahia, Cruz das Almas, Bahia, Brazil.

3 Department of Animal Science and Rural Development, Federal University of Santa Catarina, Florianópolis, Santa Catarina, Brazil.

4 Postgraduate Program in Animal Science, Federal University of Grande Dourados, Dourados, Mato Grosso do Sul, Brazil.

5 Department of Animal Science, Federal University of the South and Southeast of Pará, Xinguara, Pará, Brazil.

Corresponding author:

Rafael Henrique de Tonissi e Buschinelli de Goes

Email: rafaelgoes@ufgd.edu.br

How to cite: GOES, R.H.T.B., et al. Potential degradation and colonization time of ruminal microorganisms on the particles of different oilseeds-crushed, and its chemical composition. Bioscience Journal. 2021, 37, e37001. https://doi.org/10.14393/BJ-v37n0a2021-48122

\begin{abstract}
This study was carried out to evaluate by-product of the biodiesel industry as canola, safflower, forage turnip, and soybean crushed on the chemical composition, in situ degradability, and colonization time. Canola (Brassica napus L. var. oleifera), safflower (Carthamus tinctorius L.), forage turnip (Raphanus stivus L. var. oleiferus Metzg), and soybean (Glycine max) grains went through the oil extraction process by means of a cold pressing, resulting in the oilseeds-crushed. The treatments identification included: CAN - Canola crushed; SAF - Safflower crushed; TUR - Forage turnip crushed; and SOY - Soybean crushed. The oilseedcrushed treatments were quantified about mineral (calcium, magnesium, copper, iron, manganese, zinc, phosphorus and potassium), chemical composition (dry matter, ash, organic matter, crude protein, ether extract, neutral detergent fiber, acid detergent fiber, total carbohydrates, non-fibrous carbohydrates, and total digestible nutrient contents), In situ degradability, and colonization time. Magnesium, phosphorus, and zinc showed the greater values for TUR treatment 3.46, 27.4, 39.8, respectively, when compared to the other oilseed-crushed treatments. The TUR treatment had the lowest organic matter, whereas had the greater ( $p \leq 0.05$; TUR and SOY treatments) for the non-fibrous carbohydrates. Ether extract was not affected ( $p>0.05)$ with the different oilseed-crushed treatments. Neutral detergent fiber was affected $(p \leq 0.05)$ for CAN and SAF treatments with the greater values, 344 and $500 \mathrm{~g} / \mathrm{kg}$ of dry matter, respectively. Soluble and potentially degradable fractions for SAF treatment showed similar results. Whereas the constant rate of degradation, presented the lowest value when compared to the other treatments. Effective degradability of crude protein was greater for CAN $63.2 \%$ than SOY $65.9 \%$ treatment, which had the lowest value. Potential degradability of crude protein did not differ between treatments. Colonization time for dry matter and crude protein were similar between TUR and SOY treatments. In conclusion, oilseeds-crushed from the biodiesel production can be targeted/used, as feed with great protein and energetic potential in the ruminant's production, considering the need of correct formulation and ingredients knowledge.
\end{abstract}

Keywords: By-product. Feed Evaluation. In Situ Degradability. Rumen. 


\section{Introduction}

The performance of ruminants depends in part on the production of microbial protein, for this reason, carbohydrates and proteins are important nutrients used in feeding these animals as substrates for the microbial protein synthesis.

Ingredients that present protein from natural sources are usually expensive, but the inclusion of nitrogen compounds of non-protein origin in the diet makes it possible to reduce production costs, since it has a lower price per unit of protein equivalent. Therefore, the use of these ingredients that promote a greater release of ammonia in the rumen allows the optimization of the nitrogen use, increasing the consumption, due to the improvement in the ruminal fermentation; thus, maximizes ruminal metabolism; which will consequently benefit animal performance (Seo et al. 2010; Busanello et al. 2018). Corn (carbohydrate) is used as a starch source, being the main energy component of the concentrates. In addition, it presents characteristics that improve ruminal fermentation, mainly due to the greater efficiency of the nitrogen sources use, allowing a better use of carbohydrates and a greater microbial protein flow to the intestine (Pereira et al. 2009).

However, the grain processing practice promotes changes in physical structure and chemical composition (Nasri et al. 2008), ensuring greater ingredients degradability. Grains processing by means of cold pressing is a great alternative, since the biodiesel industries frequently do to obtain the oil. The main types of raw materials that can be used for biodiesel production are animal and vegetal oil, however as the most important biological source for industries are vegetables (Oliveira et al. 2012), highlighting the use of soybeans for the production (Souza et al. 2009; Rodrigues and Rondina 2013). In this context, many researches are being developed in order to better understand the action mechanism of ruminal microorganisms in protein and energy by-products from biodiesel; these products may alter metabolism and consequently the animal's performance.

Canola (Brassica napus L. var. oleifera) is an annual herbaceous plant of the family Brassicaceae belonging to the genus Brassica. This culture was developed from the genetic improvement of oilseed rape, with the main objective of reduce the glucosinolate and erucic acid content, which caused concern with regard to human health (OGTR 2016). Worldwide the canola is classified as the third most produced oilseed, only behind palm (34.9\%) and soy (26.8\%) production (CONAB 2013; De Mori et al. 2014; Witter and Tirelli 2014). Canola crops are mainly directed to grains production, in order to obtain the comestible oil with lowsaturated fat, biofuel oil, and to promote an animal feed source of high protein and energetic quality in the bran and/or crushed form. Safflower (Carthamus tinctorius L.), and Forage turnip (Raphanus stivus L. var. oleiferus Metzg.) are an herbaceous plant belonging to the Asteraceae and Cruciferae family, respectively. Species considered with great productive potential of comestible oil, biofuel oil, and use in animal feed.

In general, oilseeds-crushed has a high oil content, with average contribution $29 \%$ energy, and $25 \%$ crude protein, besides being rich in polyunsaturated fatty acids in its composition. In order to update the databases of biodiesel by-products used in ruminant feed, this work aimed to evaluate canola, safflower, forage turnip, and soybean crushed on the chemical composition, in situ degradability, and colonization time.

\section{Material and Methods}

This experiment was conducted at the Federal University of Grande Dourados - Department of Animal Science (Dourados, MS, Brazil); and the Laboratory for the evaluation of oilseed by-products, at the Center of Research Laboratories in Agroenergy and Environmental Conservation (LAPAC/FINEP), municipality of Dourados, state of Mato Grosso do Sul. All animals were cared for in accordance with Committee for Ethics in the use of Animals (CEUA) of the Federal University of Grande Dourados.

\section{Sample preparation and treatments}

Canola (Brassica napus L. var. oleifera), safflower (Carthamus tinctorius L.), forage turnip (Raphanus stivus L. var. oleiferus Metzg), and soybean (Glycine max) grains were obtained from the experimental farm belonging to the Federal University of Grande Dourados (Dourados, MS, Brazil). After harvesting grains, cleaning and followed by the extraction of oil from these oilseeds plants, by means of a cold type mechanical 
press, stainless steel, with extraction capacity of $150 \mathrm{~kg} / \mathrm{h}$, resulted in the biodiesel by-products (oilseedscrushed). These samples respectively to each type of oilseeds-crushed were considered as a treatment for the development of the present study. Treatments identification included: CAN - Canola crushed; SAF Safflower crushed; TUR - Forage turnip crushed; and SOY - Soybean crushed.

\section{Chemical analyses}

Minerals were analyzed according to the methodology of Malavolta et al. (1997) with readings performed in atomic absorption spectrophotometer (Analytikjena ${ }^{\circledR}$, model NovAA 300, Jena, Germany). Phosphorus and potassium were quantified by nitroperchloric solution in photocolorimeter (Micronal ${ }^{\circledR}$, model B220, OH, USA).

The chemical composition is presented as $\mathrm{g} / \mathrm{kg}$ of DM. Dry matter was determined after oven drying at $65{ }^{\circ} \mathrm{C}$ for $24 \mathrm{~h}$ and milling though a $1 \mathrm{~mm}$ screen following method ID 934.01 (AOAC, 2005). Ash content was measured by combustion at $550^{\circ} \mathrm{C}$ for $16 \mathrm{~h}$ according to method ID 942.05 (AOAC, 2005). Organic matter was calculated by method ID 967.05 (AOAC, 2005). Nitrogen concentration was determined by the Kjeldahl method ID 988.05 (AOAC, 2005). Ether extract content was determined by method ID 920.39 (AOAC, 2005). The neutral detergent fiber (NDF) content was measured according to the recommendations of Mertens (2002) using $\alpha$-amylase and was expressed inclusive of residual ash. The acid detergent fiber (ADF) content was measured by using method ID 973.18 (AOAC 2005) and was expressed inclusive of residual ash. Total carbohydrates were estimated by the procedure of Sniffen et al. (1992) as follows. Non-fibrous carbohydrates were determined as the difference between total carbohydrates and NDF. Total digestible nutrient contents (TDN) were estimated by in vitro dry matter digestibility (DMD), according to the equation: \% NDT $=9.6134+0.829 \times$ DMD (Capelle et al. 2001).

\section{In situ degradability and colonization time}

The samples were prepared and incubated according to Nocek (1988) and Huntington and Givens (1995). Ruminal incubations were performed in decreasing order of 72, 48, 36, 24, 12, 6, 3, and 0 hours using F57 filter bags (Ankom Technology, NY, USA). F57 bags were introduced directly into rumen of three steers, in triplicates per animal/incubation time, according to NRC (2001); and removed all at once and rinsed in tap water, until clean. The remaining residues from the incubation were oven dried at $65^{\circ} \mathrm{C}$ for $48 \mathrm{~h}$ and stored for later analysis to determine the variables studied.

To estimate the kinetic parameters of $\mathrm{DM}$ and $\mathrm{CP}$, the first order asymptotic model proposed by Ørskov and McDonald (1979) was used:

$$
D P=A+B\left(1-E^{-C T}\right)
$$

where: $D P, A, B, C$, and $T$ are Potential ruminal degradability; Water-soluble fraction; Insoluble fraction, but potentially degradable; Degradation rate for " $B$ " Fraction; and incubation time, respectively.

The fraction considered undegradable was calculated as follows:

$$
I=(100-(A+B))
$$

Where: $I, A$, and $B$ are Fraction undegradable; Water-soluble fraction; Insoluble fraction, but potentially degradable, respectively.

Effective degradability was determined using the following equation proposed by AFRC (1993):

$$
E D=A+[(B * C) /(C+K)]
$$

where: $E D, A, B, C$, and $K$ are Effective degradability; Water-soluble fraction; Insoluble fraction, but potentially degradable; Degradation rate for "B", and Particle passage rate in the rumen, defined in this research as 2,5 , and $8 \%$ per hour, due to low, medium and high feed consumption levels, respectively.

After adjusting the data to the model of $\varnothing$ rskov and McDonald (1979), using the disappearance value obtained at time zero $\left(A^{\prime}\right)$, the colonization time was determined for dry matter and crude protein, according to adequacy proposed by Patiño et al. (2001), being the parameters were estimated by Gaus Newton's algorith:

$$
\mathrm{CT}=\left[-\mathrm{IN}\left(\mathrm{A}^{\prime}-\mathrm{A}-\mathrm{B}\right) / \mathrm{C}\right]
$$

where: $C T, I N, A^{\prime}, A, B$, and $C$ are Colonization time; Indegreeable fraction; Disappearance value obtained at time zero; Water-soluble fraction; Insoluble fraction, but potentially degradable; and Degradation rate for "B", respectively. 


\section{Statistical analyses}

Minerals statistical analysis were determined by quantitative descriptive analysis. The model included the fixed effects of oilseeds-crushed diets according the following equation:

$$
\mathrm{Yij}=\mu+\mathrm{Ti}+\mathrm{eij}
$$

where: Yij, $\mu, T i$, eij are Dependent variables; Mean value common to all observations; Fixed effect of essential oils diets; and the error term, respectively. Differences between means were evaluated using Tukey's Test $(p \leq 0.05)$.

\section{Results}

Calcium, magnesium, phosphorus, manganese, and iron showed the greater values for CAN treatment (Table 1). Potassium was greater for SOY treatment, while the lowest value iron, when compared to the other oilseed-crushed treatments. The SAF treatment had the lowest manganese while had the greater value for copper and zinc.

Table 1. Composition of the oilseeds-crushed treatment mineral, as macro-minerals ( $\mathrm{g} / \mathrm{kg}$ of $\mathrm{DM})$, and microminerals ( $\mathrm{mg} / \mathrm{kg}$ of DM) content ${ }^{1}$.

\begin{tabular}{lllll}
\hline Macronutrients & CAN & SAF & TUR & SOY \\
\hline Calcium & 4.69 & 1.68 & 4.00 & 2.50 \\
Magnesium & 3.25 & 2.88 & 3.46 & 2.63 \\
Potassium & 0.79 & 0.78 & 1.08 & 1.85 \\
Phosphorus & 22.3 & 19.8 & 27.4 & 18.8 \\
\hline Micronutrients & & & & \\
\hline Copper & 4.47 & 18.7 & 6.71 & 8.53 \\
Manganese & 35.9 & 18.3 & 21.3 & 20.7 \\
Iron & 470 & 213 & 195 & 167 \\
Zinc & 25.0 & 41.7 & 39.8 & 31.2 \\
\hline
\end{tabular}

${ }^{1}$ CAN = Canola crushed; SAF = Safflower crushed; TUR = Forage turnip crushed; and SOY = Soybean crushed.

Regarding chemical composition the dry matter was significantly greater for SOY treatment, whereas the acid detergent fiber had the lowest $(p<0.05)$ when compared to other oilseed-crushed treatments (Table $2)$. The TUR treatment had the lowest organic matter, while smaller the greater $(p<0.05)$ for the non-fibrous carbohydrates. The SAF treatment had the lowest Ash, crude protein, and total digestible nutrients, but the greater $(p<0.05)$ for total carbohydrates when compared to the other oilseed-crushed treatments. Ether extract was not affected $(p>0.05)$ with the different oilseed-crushed treatments. Neutral detergent fiber was affected $(p<0.05)$, therefore, CAN and SAF treatments present the greater values when compared to TUR and SOY treatments.

Table 2. Chemical composition of oilseeds-crushed treatment (g/kg of DM) ${ }^{1}$.

\begin{tabular}{lccccc}
\hline Items & CAN & SAF & TUR & SOY & SE \\
\hline Dry matter & $915^{\mathrm{c}}$ & $928^{\mathrm{b}}$ & $918^{\mathrm{c}}$ & $940^{\mathrm{a}}$ & 0.44 \\
Organic matter & $966.1^{\mathrm{ab}}$ & $982.5^{\mathrm{a}}$ & $960.4^{\mathrm{c}}$ & $970.1^{\mathrm{b}}$ & 0.62 \\
Ash & $33.9^{\mathrm{bc}}$ & $17.5^{\mathrm{c}}$ & $39.6^{\mathrm{a}}$ & $29.9^{\mathrm{ab}}$ & 0.19 \\
Crude protein & $407^{\mathrm{ab}}$ & $242^{\mathrm{c}}$ & $384^{\mathrm{b}}$ & $443^{\mathrm{a}}$ & 0.36 \\
Ether extract & 160 & 155 & 172 & 171 & 0.04 \\
Neutral detergent fiber & $344^{\mathrm{b}}$ & $500^{\mathrm{a}}$ & $193^{\mathrm{c}}$ & $161^{\mathrm{c}}$ & 7.94 \\
Acid detergent fiber & $271^{\mathrm{ab}}$ & $319^{\mathrm{a}}$ & $218^{\mathrm{b}}$ & $97.3^{\mathrm{c}}$ & 0.20 \\
Non-fibrous carbohydrates & $63.2^{\mathrm{b}}$ & $85.9^{\mathrm{b}}$ & $210^{\mathrm{a}}$ & $195^{\mathrm{a}}$ & 0.41 \\
Total carbohydrates & $409^{\mathrm{b}}$ & $586^{\mathrm{a}}$ & $404^{\mathrm{b}}$ & $356^{\mathrm{b}}$ & 0.77 \\
Total digestive nutrients & $712^{\mathrm{b}}$ & $624^{\mathrm{c}}$ & $800^{\mathrm{b}}$ & $818^{\mathrm{a}}$ & 0.84 \\
\hline
\end{tabular}

${ }^{1}$ CAN = Canola crushed; SAF = Safflower crushed; TUR = Forage turnip crushed; and SOY = Soybean crushed.

abc Values with different letters in the same row are different by Tukey test ( $p \leq 0.05)$; (SAS, 2004). 
Soluble and potentially degradable fractions for SAF treatment (dry matter) were similar, but the lowest result for the constant rate of degradation when compared to SOY treatment (Table 3). Whereas for crude protein the constant rate of degradation values was similar between SAF and SOY treatments. While the soluble fraction for SAF treatment was greater than SOY treatment, but lowest when compared to the potentially degradable fraction.

Table 3. Degradation fraction, effective degradability, and potential degradability of the different oilseedscrushed $^{1,2}$.

\begin{tabular}{lccccccccc}
\hline Items & A & B & C & I & ED2 & ED5 & ED8 & PD & $r^{2}$ \\
\hline Treatment (\% DM) & & & & & & & & & \\
$\quad$ CAN & 48.4 & 32.2 & 6.76 & 19.3 & 73.3 & 66.9 & 63.2 & 80.4 & 0.88 \\
$\quad$ SAF & 39.2 & 50.0 & 8.30 & 10.8 & 79.5 & 70.4 & 64.6 & 89.2 & 0.72 \\
$\quad$ TUR & 51.8 & 39.2 & 3.35 & 9.01 & 76.4 & 67.5 & 63.4 & 87.5 & 0.88 \\
$\quad$ SOY & 43.1 & 53.1 & 3.76 & 3.78 & 77.7 & 65.9 & 60.1 & 92.7 & 0.97 \\
Treatment (\% CP) & & & & & & & & & \\
$\quad$ CAN & 53.8 & 29.8 & 11.5 & 16.3 & 79.3 & 74.6 & 71.4 & 83.7 & 0.85 \\
SAF & 48.5 & 33.5 & 6.10 & 17.9 & 73.7 & 66.9 & 63.0 & 81.6 & 0.84 \\
TUR & 55.1 & 24.8 & 4.61 & 20.1 & 72.4 & 67.1 & 64.2 & 79.1 & 0.57 \\
$\quad$ SOY & 27.6 & 54.7 & 7.33 & 17.7 & 70.6 & 60.1 & 53.7 & 82.0 & 0.90 \\
\hline
\end{tabular}

${ }^{1}$ CAN = Canola crushed; SAF = Safflower crushed; TUR = Forage turnip crushed; and SOY = Soybean crushed.

${ }^{2} \mathrm{~A}=$ Water-soluble fraction; $\mathrm{B}=$ Potentially degradable faction; $\mathrm{C}=$ Degradation rate; $\mathrm{I}=$ Indegreeable fraction; $\mathrm{ED}=\mathrm{Effective}$ degradability at 2,5 , and $8 \%$ per hour; PD = Potential degradability.

Effective degradability (dry matter) at 2, 5, and 8 percent/hour showed the greater value that was $46.3 \%$ for SAF treatment, while the other oilseed-crushed treatments were similar. The three percentages of effective degradability (crude protein) were greater for CAN treatment when compared to the SOY treatment that had lowest value. Potential degradability (PD) of crude protein did not differ between treatments, while for the dry matter the greater values were for TUR and SOY treatments. Colonization time for dry matter and crude protein were similar between TUR and SOY treatments (Table 4).

Table 4. Colonization time (lag time) in hours of the different oilseeds-crushed ${ }^{1}$.

\begin{tabular}{lcc}
\hline Treatment & Dry matter & Crude protein \\
\hline CAN & 6.17 & 5.56 \\
SAF & 6.40 & 3.51 \\
TUR & 7.06 & 6.29 \\
SOY & 7.25 & 6.61 \\
\hline
\end{tabular}

${ }^{1}$ CAN = Canola crushed; SAF = Safflower crushed; TUR = Forage turnip crushed; and SOY = Soybean crushed.

\section{Discussion}

Manganese is the most effective activator of the glycosyltransferase enzymes, involved in the mucopolysaccharides and glycoproteins synthesis. Several enzymatic systems are activated by manganese, and there is concentration of this micro-mineral in mitochondria, its action is in the partial regulation of oxidative phosphorylation (Suttle 2010).

Iron is a vital mineral for cell homeostasis, being essential for the oxygen transport, for DNA synthesis, and energy metabolism. This mineral is an important cofactor for mitochondrial respiratory chain enzymes and nitrogen fixation. In mammals it is mainly used in the hemoglobin synthesis, however the iron deficiency will cause anemia, whereas, the iron accumulation or excess is extremely harmful to the tissues.

As mentioned, the macro-minerals and micro-minerals are of great importance for the integrity of the animal's organism. In the present study the canola, safflower, and forage turnip crushed presented the greater concentrations of these nutrients when compared to the soybean crushed. Whereas, the minerals availability to the animal are directly related to factors such as: source (feed), availability, bioavailability, 
transport, body storage, body interaction and cell utilization mechanism (Grotto et al. 2008; Marciano et al. 2015).

Dry matter content of oilseed-crushed (Table 2), SOY treatment showed the lowest variation. This variation between the treatments can be explained due to the specific ability of each oilseed to absorb moisture after the grain pressing process. However, all oilseed-crushed treatments are within the optimal range for storage, this range is between 6 to 11\% (Custódio et al. 2005; Souza et al. 2009).

Factors such as genotype, environmental conditions, and efficiency of oil extraction allow variations in crude protein content. In the present study, the type of oil extraction was standardized (pressing), in order to minimize such differences, and thus, to promote the same condition for all treatments. In this way the value obtained for the CAN treatment is above the value found by Tomm (2005), reaffirming that the canola crushed is an excellent protein source with quality, due to the high lysine content in its composition, besides not having any anti-nutritional factor (Abdalla et al. 2008). Thus, this by-product can be classified as a great potential feed in ruminant diets.

Ether extract was not affected between the treatments, possibly explained because the extraction process occurred equally for all oilseed treatments. The ether extract values of the present study are superior to the results found by Brás et al. (2011), working with the forage turnip and safflower crushed characterization, which verified lipid contents of 125 and $103 \mathrm{~g} / \mathrm{kg}$ respectively. It is commonly attributed a maximum limit of 6-7\% of ether extract dry matter in the ruminant's diet (Kozloski, 2011), thus avoiding the change in rumen degradation of the fiber. However, this limit may vary due to the type of basal diet (forage or concentrate); unsaturation grade of fatty acids; physical protection of lipid, as occurs with whole grains or oilseeds-crushed; and due to the high energy density of the diet.

CAN and SAF treatments presented the greater concentrations for neutral detergent fiber and acid detergent fiber, which favors their use as a fiber source in the lactating cows' diet, thus avoiding the incidence of metabolic disorders associated with the high nutritional requirements of this animal category. Fiber acts as a ruminal filling factor, besides the maintenance capacity of ruminal microorganisms. According to Detmann (2010), this microorganism's maintenance promotes satisfactory levels of animal performance when the diet is predominantly composed of forage feed, therefore TUR and SOY treatments would not inhibit rumen digestion transit due to low neutral detergent fiber contents. According to this statement Goes et al. (2012) evaluating the replacement of soybean meal by sunflower crushed in cattle diet, verified an increase in the acid detergent fiber percentage in the diet, but this increase did not affect animal performance. Total digestive nutrients values presented a conduct inversely proportional to the fiber values, demonstrating the possibility to indicate with good accuracy the feed energy level in static prediction models of consumption.

Chemical characterization of the oilseeds-crushed in this study has its importance, but information regarding the fractions of feed degradation and digestion rate is necessary in order to synchronize the nitrogen and energy availability in the rumen (Goes et al. 2010; Goes et al. 2011; Bassi et al. 2012); increase the microorganism's efficiency; nutrient digestion; and avoid high losses caused by fermentation.

In relation to the kinetic parameters, the " $A$ " fraction represents the most soluble part of feed, important for fermentation process of microorganisms in the ruminal environment, which characterizes the rapid energy release after being ingested by the animal. TUR treatment presented the greater values for both dry matter and crude protein degradation (Table 3) with a hydrolysis percentage of 51.8 and 55.1, respectively, these values being similar to that found by Marciano et al. (2008). The fraction "B" represents the part that is potentially degradable from a feed, and therefore digested. In general, TUR and SOY treatments presented satisfactory values for the " $A$ " and "B" fractions, demonstrating the potential of these oilseeds-crushed to provide their nutrients. Effective degradability at 2, 5, and $8 \%$ per hour for dry matter were greater for TUR and SOY treatments, these results corroborating with the indegreeable fraction, which were the lowest values found for these two treatments.

CAN and SAF treatments had the greater values for the indegreeable fraction; the explanation is because these two treatments present high contents of acid detergent fiber in their chemical composition (Table 2), and the fiber degradation is connected to feed digestibility. However, the degradation may be greater or lower according to the content of this fiber type, since the lignin present in the acid detergent fiber is not used (Silva and Queiroz, 2002). 
Colonization time is the parameter that relates to capacity that the microorganisms initiate the feed degradation, through the fibrous fraction (Patussi et al. 2015). In the present study, TUR and SOY treatments are in accordance with the already presented results of chemical composition and degradation efficiency (Table 2, 3). Therefore, the low values for colonization time (lag time) from CAN and SAF treatments (Table 4), are correlated with the amount of neutral detergent fiber and acid detergent fiber, that is, the amount of cell wall can negatively interfere in the microorganism's adherence to the substrate.

\section{Conclusions}

Oilseeds-crushed from the biodiesel production can be targeted/used, as feed with great protein and energetic potential in the ruminants production, considering the need of correct formulation and ingredients knowledge.

Authors' Contributions: GOES, R.H.T.B.: Conception and design, acquisition of data, analysis and interpretation of data, drafting the manuscript, final approval; SOUZA, K.A.: Analysis and interpretation of data, drafting the manuscript, final approval; OSMARI, M.P.: Acquisition of data, analysis and interpretation of data, drafting the manuscript, final approval; CARDOSO, T.J.L.: Acquisition of data, analysis and interpretation of data; OLIVEIRA, R.T.: Acquisition of data, analysis and interpretation of data; SILVA, N.G.: Acquisition of data, analysis and interpretation of data; GANDRA, J.R.: Analysis and interpretation of data, drafting the manuscript, final approval; SOUZA, L.C.F.: Conception and design, acquisition of data, analysis and interpretation of data.

Conflicts of Interest: The authors declare no conflicts of interest.

Ethics Approval: Approved by Committee for Ethics in the use of Animals of the Federal University of Grande Dourados. CEUA: $004 / 2013$.

Acknowledgments: The authors would like to thank the funding for the realization of this study provided by the Brazilian agencies CAPES (Coordenação de Aperfeiçoamento de Pessoal de Nível Superior - Brasil), Finance Code 001; CNPq (Conselho Nacional de Desenvolvimento Científico e Tecnológico - Brasil), Finance Code 481832/2009-2 and 501985/2009-3; and FUNDECT (Fundação de Apoio ao Desenvolvimento do Ensino, Ciência e Tecnologia do Estado de Mato Grosso do Sul - Brasil). The authors would also like to thank the technique Maria Gizelma de Menezes Gressler, for her assistance in conducting laboratory analyses.

\section{References}

ABDALLA, A.L., et al. Utilização de subprodutos da indústria de biodiesel na alimentação de ruminantes. Revista Brasileira de Zootecnia. 2008, 37, 260-268. http://dx.doi.org/10.1590/S1516-35982008001300030

Agricultural and Food Research Council (AFRC). Energy and Protein requeriments of ruminant. Wallingford: CAB International, 1993. Available from: https://www.cabi.org/bookshop/book/9780851988511/

Association of Official Analytical Chemistry (AOAC). Official methods of analysis of AOAC International. 18 $8^{\text {th }}$ ed. Gaithersburg: AOAC International, 2005.

BASSI, M.S., et al. Oilseeds in Zebu cattle dieta: intake, digestibility and performance. Revista Brasileira de Zootecnia. 2012, 41(2), 353-359. https://doi.org/10.1590/S1516-35982012000200018

BRÁS, P. Caracterização nutricional de co-produtos da extração de óleo em grãos vegetais em dietas de ovinos. Nova Odessa: Instituto de Zootecnia, 2011. Available from: http://www.iz.sp.gov.br/pdfs/1301660280.pdf

BUSANELLO, M., et al. A meta-analysis on in situ ruminal degradability of grains and meal for energy concentrate feeds. Emirates Journal of Food \& Agriculture. 2018, 30(3), 240-244. https://doi.org/10.9755/ejfa.2018.v30.i3.1638

CAPELLE, E.R., et al. Estimativas de valor energético a partir de características químicas e bromatológicas dos alimentos. Revista Brasileira de Zootecnia. 2001, 30, 1837-1856. http://dx.doi.org/10.1590/S1516-35982001000700022

Companhia Nacional de Abastecimento (CONAB). Conjuntura mensal da Canola, 2013. Available from:

http://www.conab.gov.br/OlalaCMS/uploads/arquivos/13_04_09_10_27_26_boletim_graos_abril_2013.pdf.

CUSTÓDIO, D.P., et al. Ração: alimento animal perecível. Revista Eletrônica Faculdade Montes Belos. 2005, 1(2), 131-147.

DeMORI, C., FERREIRA, P.E.P. and TOMM, G.O. Aspectos Econômicos e Conjunturais da Cultura da Canola no Mundo e no Brasil. Passo Fundo: Embrapa Trigo, 2014. Available from: https://ainfo.cnptia.embrapa.br/digital/bitstream/item/103763/1/2014-documentos-online149.pdf

DETMANN, E., 2010. Fibra na nutrição de novilhas leiteiras. In: PEREIRA, E.S., PIMENTEL, P.G., QUEIROZ, A. C. and MIZUBUTI, I.Y, eds. Novilhas Leiteiras, Fortaleza: Graphiti, pp. 253-302.

GOES, R.H.T.B., et al. Torta de girassol em substituição ao farelo de soja nos suplementos de novilhas: desempenho e características de carcaça. Revista Brasileira de Saúde e Produção Animal. 2012, 13(2), 396-409. https://doi.org/10.1590/S1519-99402012000200009 
GOES, R.H.T.B., et al. Degradabilidade in situ dos grãos de crambe, girassol e soja, e de seus coprodutos em ovinos. Acta Scientiarum. Animal Sciences. 2010, 32(3), 271-277. http://dx.doi.org/10.4025/actascianimsci.v32i3.7913

GROTTO, H.Z.W. Metabolismo do ferro: uma revisão sobre os principais mecanismos envolvidos em sua homeostase. Revista Brasileira de Hematologia e Hemoterapia. 2008, 30(5), 390-397. http://dx.doi.org/10.1590/S1516-84842008000500012

HUNTINGTON, J.A. and GIVENS, D.I. The in situ technique for studying the rumen degradation of feeds: A review of the procedure. Nutrition Abstracts and Review (Serie B). 1995, 65, 63-93.

KOZLOSKI, G.V. Bioquímica dos ruminantes. Santa Maria: Editora UFSM, 2011.

MALAVOLTA, E., VITTI, G.C. and OLIVEIRA, S.A. Avaliação do estado nutricional das plantas: princípios e aplicações. 2nd ed. Piracicaba: Potafós, 1997.

MARCIANO, R., et al. Avaliação do resíduo de nabo forrageiro extraído da produção de biodiesel como suplemento para bovinos de corte em pastagens. Revista Brasileira de Saúde e Produção Animal. 2008, 9(1), 45-46.

MERTENS, D.R. Gravimetric determination of amylase-treated neutral detergent fiber in feeds with refluxing in beakers or crucibles: collaborative study. Journal of AOAC International. 2002, 85(6), 1217-1240.

NASRI, M.H.F., et al. Effect of heat processing on ruminal degradability and intestinal disappearance of nitrogen and amino acids in Iranian whole soybean. Livestock Science. 2008, 113(1), 43-51. https://doi.org/10.1016/j.livsci.2007.02.017

National Research Council (NRC). Nutrient requirements of dairy cattle. 7th ed. Washington: National Academy Press, 2001.

NOCEK J.E. In situ and others methods to estimate ruminal protein and energy digestibility. Journal of Dairy Science. 1988, 71, $2051-2069$. https://doi.org/10.3168/jds.S0022-0302(88)79781-7

Office of the Gene Technology Regulator (OGTR). The biology of Brassica napus L. (Canola) and Brassica juncea (L.) Czern. \& Coss. (Indian mustard). Austrália: Office of the Gene Technology Regulator, 2016. Available from:

https://www1.health.gov.au/internet/ogtr/publishing.nsf/Content/5DCF28AD2F3779C4CA257D4E001819B9/\$File/Biology\%20of\%20Canola\%2 Oand\%20Indian\%20mustard\%20February\%202017.pdf

OLIVEIRA, R.L., et al. Biodiesel industry by-products used for ruminant feed. Revista Colombiana de Ciencias Pecuarias. 2012, 25(4), 625-638.

$\emptyset$ RSKOV, E.R. and McDONALD, I. The estimation of protein degradability in the rumen from incubation measurements weighed according to rate of passage. Journal of Agricultural Science. 1979, 92, 499-503. https://doi.org/10.1017/S0021859600063048

PATINÕ, H.O., et al. Avaliação de métodos de ajuste da curva de degradação ruminal da FDN em forragens. In: Reunião Anual da Sociedade Brasileira de Zootecnia, Piracicaba. Anais... Piracicaba: SBZ. p.970, 2001.

PATUSSI, R.A., et al. Composição química, degradabilidade ruminal e tempo de colonização de suplementos concentrados com torta de crambe. Boletim de Indústria Animal. 2015, 72(3), 200-208. https://doi.org/10.17523/bia.v72n3p200

PEREIRA, L.G.R., et al., 2009. O milho na alimentação de gado de leite. In: GONÇALVES, L.C., BORGES, I. and FERREIRA, P.D.S, eds. Alimentos para gado de leite, Belo Horizonte: FEPMVZ, pp. 240-269.

RODRIGUES, F.V. and RONDINA, D. Alternativas de uso de subprodutos da cadeia do Biodiesel na alimentação de ruminantes: Glicerina bruta. Acta Veterinaria Brasilica. 2013, 7, 1-99. https://doi.org/10.21708/avb.2013.7.2.2801

SAS Institute Inc. SAS/STAT ${ }^{\circledR} 9.1$ User's Guide. Cary, NC: SAS Institute Inc, 2004. Available from: https://support.sas.com/documentation/onlinedoc/91pdf/sasdoc_91/stat_ug_7313.pdf

SEO, J.K., et al. Effects of synchronization of carbohydrate and protein supply on ruminal fermentation, nitrogen metabolism and microbial protein synthesis in Holstein steers. Asian Australasian Journal of Animal Science. 2010, 23(11), 1455-1461.

https://doi.org/10.5713/ajas.2010.10247

SILVA, D.J. and QUEIROZ, A.C. Análise de alimentos: métodos químicos e biológicos. 3rd ed. Viçosa: UFV, 2002.

SNIFFEN, C.J., et al. A net carbohydrate and protein system for evaluating cattle diets: II. Carbohydrate and protein availability. Journal of Animal Science. 1992, 70(11), 3562-3577. https://doi.org/10.2527/1992.70113562x

SOUZA, A.D.V., et al. Caracterização química de sementes e tortas de pinhão-manso, nabo-forrageiro e crambe. Pesquisa Agropecuária Brasileira. 2009, 44(10), 1328-1335. https://doi.org/10.1590/S0100-204X2009001000017

SUTTLE, N.F. Mineral Nutrition of Livestock. 4th ed. Cambridge: CABI North American Office, 2010.

TOMM, G.O. Situação em 2005 e perspectivas da cultura de canola no Brasil e em países vizinhos. Passo Fundo: Embrapa Trigo, 2005. Available from: http://www.cnpt.embrapa.br/biblio/bp/p_bp26.htm

WITTER, S. and TIRELLI, F., 2014. Polinizadores nativos presentes em lavouras de canola no Rio Grande do Sul. In: WITTER, S., NUNES-SILVA, P. and BLOCHTEIN, B., eds. Abelhas na polinização de canola - benefícios ambientais e econômicos. Porto Alegre: Edipucrs, p. 44. 
This is an Open Access article distributed under the terms of the Creative Commons Attribution License, which permits unrestricted use, distribution, and reproduction in any medium, provided the original work is properly cited. 